\title{
DETERMINAN KEPEMILIKAN JAMINAN KESEHATAN PENDUDUK LANJUT USIA DI INDONESIA
}

\author{
(Determinant of Health Insurance Ownership of The Elderly in Indonesia)
}

Dwi Agus Styawan

BPS Kabupaten Kebumen

JL. Arungbinang $17 \mathrm{~A}$, Kebumen

E-mail: dwi.agus@bps.go.id

\begin{abstract}
ABSTRAK
Cakupan universal kesehatan atau Universal Health Coverage (UHC) merupakan salah satu target yang ditetapkan dalam SDGs. Penelitian ini bertujuan untuk mengkaji pencapaian UHC penduduk lansia dan faktorfaktor yang mempengaruhi kepemilikan jaminan kesehatan penduduk lansia di Indonesia. Sumber data penelitian ini adalah data Susenas 2017, dengan variabel-variabel yang diteliti antara lain wilayah tempat tinggal, jenis kelamin, status perkawinan, umur, tingkat pendidikan, keluhan kesehatan, dan status ekonomi (dalam kajian ini didekati dengan kelompok pengeluaran). Metode yang digunakan dalam penelitian ini adalah metode kuantitatif dengan Uji Chi Square sebagai metode untuk menguji hubungan/perbedaan secara statistik antar variabel yang diteliti. Hasil penelitian menunjukkan empat hal. Pertama, penduduk lansia di Indonesia didominasi oleh perempuan, berumur 60-69 tahun, berstatus kawin, berpendidikan SD ke bawah, tinggal di wilayah pedesaan dan berada pada rumah tangga dengan kelompok pengeluaran 40 persen terbawah. Kedua, pencapaian UHC terhadap penduduk lansia relatif baik walaupun belum mampu menjangkau seluruh penduduk lansia di Indonesia. Ketiga, penduduk lansia di Indonesia masih tergantung pada bantuan pembiayaan jaminan kesehatan dari pemerintah. Keempat, determinan kepemilikan jaminan kesehatan penduduk lansia di Indonesia adalah wilayah tempat tinggal, jenis kelamin, status perkawinan, tingkat pendidikan, keluhan kesehatan dan status ekonomi. Oleh karena itu, sebagai upaya dalam mewujudkan target SDG's, pemerintah harus terus memperluas jangkauan UHC melalui program-program perlindungan kesehatan bagi penduduk lansia. Program-program ini hendaknya juga harus didasarkan pada karakteristik penduduk lansia di setiap wilayah Indonesia.
\end{abstract}

Kata kunci: Jaminan Kesehatan, Lansia, SDG's, Cakupan Universal Kesehatan

\begin{abstract}
Universal health coverage (UHC) is one of the targets in the SDGs. This study aims to examine the UHC achievement of the elderly and the factors that influence the ownership of health insurance for the elderly in Indonesia. The data source of this study is Susenas 2017, with variables examined including the area of residence, gender, marital status, age, education level, health complaints, and economic status (in this study approached with expenditure groups). The method used in this study is a quantitative method with Chi Square Test as a method to test the relationship / differences statistically between the variables studied. The results showed four things. First, the elderly in Indonesia is dominated by women, aged 60-69 years, married, educated in elementary school and below, living in rural areas and in households with the lowest 40 percent expenditure group. Secondly, UHC's achievement of the elderly is relatively good although it has not been able to reach all the elderly in Indonesia. Third, the elderly in Indonesia is still dependent on health insurance financing assistance from the government. Fourth, determinants of health insurance ownership of the elderly in Indonesia are residential area, gender, marital status, education level, health complaints and economic status. Therefore, as an effort to realize the SDG's target, the government must continue to expand the reach of UHC through health protection programs for the elderly. These programs should also be based on the characteristics of the elderly population in each region of Indonesia.
\end{abstract}

Keywords: Health Insurance, Elderly, SDG's, Universal Health Coverage 


\section{PENDAHULUAN}

Kesehatan merupakan salah satu kebutuhan pokok bagi kehidupan penduduk lanjut usia (lansia). Pembangunan kesehatan pun menjadi salah satu tujuan dalam Sustainable Development Goals (SDG's), tepatnya tujuan ketiga yakni menjamin kehidupan yang sehat dan meningkatkan kesejahteraan penduduk di segala usia (BPS, 2018a). Pada tujuan ini, SDG's telah menetapkan beberapa target yang harus dicapai setiap negara. Salah satu target tersebut adalah memastikan cakupan kesehatan yang berkualitas bagi setiap orang, atau kemudian disebut dengan Cakupan Kesehatan Universal (Universal Health Coverage/UHC). Menurut World Health Organization (WHO), UHC merupakan suatu sistem pembiayaan kesehatan yang menjamin setiap penduduk memiliki akses secara adil dan merata terhadap pelayanan kesehatan yang dibutuhkan, berkualitas, dan terjangkau secara finansial, baik pelayanan promotif, kuratif, preventif, maupun rehabilitatif (Agustina et al., 2019).

Beberapa studi terdahulu membuktikan bahwa terdapat dampak positif antara pelaksanaan UHC terhadap perekonomian. Hasil kajian yang dilakukan oleh Council and Foreign Relations menyatakan bahwa UHC dapat meningkatkan pertumbuhan tenaga kerja, pertumbuhan gaji, dan produktivitas tenaga kerja (Ahoobim, Garrett, Hausman, \& Huang, 2012). Selain itu, UHC juga dapat menurunkan tingkat kemiskinan melalui proteksi keuangan saat terjadi shock akibat masalah kesehatan (WHO, 2015). Hasil-hasil ini senada dengan hasil riset tentang penerapan UHC di Indonesia yang dilakukan oleh BPJS Kesehataan dan LPEM FEB Universitas Indonesia yang menyatakan bahwa dalam jangka pendek, UHC dapat meningkatkan output dan tenaga kerja sektor lain, sedangkan dalam jangka panjang program UHC dapat meningkatkan modal manusia melalui peningkatan angka harapan hidup, serta pada akhirnya UHC akan mampu meningkatkan pertumbuhan ekonomi (Dartanto et al., 2017). Dengan demikian berbagai hasil kajian ini menunjukkan bahwa UHC merupakan hal yang penting untuk segera diterapkan secara menyeluruh di Indonesia.

Pada saat ini, UHC sebagai bagian dari reformasi sistem kesehatan telah dilaksanakan oleh hampir setengah negara di dunia dengan berbagai tingkatan pendapatan (Boerma et al., 2014). Brazil, Rusia, India, China dan Afrika Selatan mewakili hampir setengah populasi di dunia yang berkomitmen untuk memastikan pelaksanaan dan pencapaian UHC (Marten et al., 2014). Indonesia sebagai salah satu negara yang sedang berkembang pun telah mengadopsi sistem kesehatan ini. Pada tahun 2014, pemerintah Indonesia menerapkan sistem Jaminan Kesehatan Nasional (JKN) bagi setiap penduduknya. Sistem ini diberlakukan secara bertahap dan ditargetkan pada tahun 2019 dapat mencakup seluruh penduduk Indonesia.

Dewasa ini, penduduk lanjut usia (lansia) menjadi salah satu fokus utama pembangunan di berbagai negara. Hal ini sebagai konsekuensi dari perubahan struktur demografi dunia. Secara global, populasi dunia saat ini telah memasuki era penuaan penduduk atau Ageing Population, yakni jumlah penduduk berusia 60 tahun ke atas telah melebihi 7 persen populasi. Hasil kajian Perserikatan Bangsa-Bangsa (PBB) menyatakan bahwa pada tahun 2017, populasi penduduk lansia di dunia mencapai 962 juta jiwa. Jumlah ini meningkat lebih dari dua kali lipat dibandingkan tahun 1980 yang hanya 382 juta jiwa. Populasi penduduk lansia di dunia diproyeksikan akan terus meningkat hingga pada tahun 2050 mencapai sekitar 2,1 miliar jiwa (United Nations, 2017).

Fenomena Ageing Population pun juga terjadi di Indonesia, sebagai dampak dari baby boom yang terjadi pada beberapa puluh tahun lalu. Hasil sensus penduduk 2010, menyatakan bahwa Indonesia saat ini termasuk ke dalam 5 besar negara dengan jumlah penduduk lansia terbanyak di dunia (Misnaniarti, 2017). Selama kurun waktu hampir 50 tahun (1971-2018), persentase penduduk lansia Indonesia meningkat sekitar dua kali lipat. Pada tahun 2018, persentase lansia mencapai 9,27 persen atau sekitar 24,49 juta orang (BPS, 2018b). Pada masa mendatang, jumlah ini diproyeksikan akan terus meningkat. BPS memproyeksikan bahwa pada tahun 2045, Indonesia akan memiliki sekitar 63,31 juta penduduk lansia atau hampir mencapai 20 persen populasi. Bahkan, proyeksi PBB juga menyebutkan bahwa persentase penduduk lansia Indonesia akan mencapai 25 persen pada tahun 2050 atau sekitar 74 juta jiwa.

Pada satu sisi, peningkatan jumlah lansia mengindikasikan keberhasilan program-program pelayanan kesehatan yang selama ini telah dijalankan pemerintah. Namun pada sisi lain, peningkatan jumlah lansia juga akan menimbulkan tantangan tersendiri dalam perencanaan 
pembangunan nasional. Tantangan ini terutama terkait dengan bagaimana mempersiapkan penduduk lansia menjadi mandiri, sehat, aktif, dan produktif. Dalam konteks ini, kesehatan menjadi faktor krusial bagi penduduk lansia. Bagaimanapun juga, panjangnya masa hidup pada lansia tidak akan berarti tanpa disertai kesehatan yang prima. Dengan kata lain, kehidupan yang mandiri, aktif, dan produktif akan tercapai jika penduduk lansia memiliki kesehatan yang berkualitas.

Program jaminan kesehatan bagi penduduk lansia merupakan salah satu upaya pemerintah dalam mewujudkan kesehatan yang berkualitas. Program ini sebagai bentuk konkret penerapan sistem JKN sekaligus upaya menjalankan amanah SDG's yakni UHC di Indonesia. Pada dasarnya, terdapat lima jenis jaminan kesehatan yang dimiliki penduduk. Kelima jenis jaminan kesehatan tersebut adalah penerima bantuan iuran, non penerima bantuan iuran, jaminan kesehatan daerah, asuransi swasta, dan asuransi perusahaan/kantor.

Secara umum, berdasarkan aspek cakupan kepesertaan, perkembangan jumlah peserta jaminan kesehatan di Indonesia relatif baik. Selama periode 2014-2019, cakupan kepesertaan jaminan kesehatan di Indonesia terus mengalami peningkatan. Pada awal penerapan sistem JKN, yakni tahun 2014, jumlah peserta jaminan kesehatan tercatat sebanyak 133,4 juta jiwa atau sekitar 49 persen dari total penduduk Indonesia. Pada tahun-tahun berikutnya, cakupan kepesertaan ini terus meningkat, hingga per 31 Agustus 2019 menjadi 221,3 juta jiwa atau lebih dari 83,7 persen populasi (BPJS Kesehatan, 2019). Hal ini menunjukkan keberhasilan pemerintah baik dalam melakukan sosialisasi secara langsung kepada tokoh masyarakat/agama, pekerja, pemberi kerja/perusahaan, dan para pengambil kebijakan di daerah, ataupun promosi secara tidak langsung melalui berbagai media. Keberhasilan ini merupakan capaian yang perlu diapresiasi, mengingat apabila dibandingkan dengan negara lain, penerapan sistem JKN di Indonesia relatif jauh lebih singkat. Dalam regional Asia dengan budaya dan kondisi wilayah yang relatif sama dengan Indonesia, Korea Selatan dan Jepang mencapai UHC masing-masing setelah 26 dan 36 tahun (BPJS Kesehatan, 2016).

Capaian kepesertaan jaminan kesehatan masih jauh dari target pemerintah yakni mencapai UHC pada tahun 2019, dengan cakupan kepesertaan minimal 95 persen dari penduduk Indonesia. Salah satu tantangan dalam memenuhi target ini adalah masih relatif rendahnya kepesertaan jaminan kesehatan penduduk lansia. Hasil Survei Sosial Ekonomi Nasional (Susenas) tahun 2018 mencatat bahwa terdapat 68,48 persen penduduk lansia yang telah memiliki jaminan kesehatan (BPS, 2018b). Hal ini berarti dari tiga penduduk lansia, satu diantaranya tidak memiliki jaminan kesehatan. Kondisi ini tentu harus menjadi perhatian serius bagi pemerintah. Bagaimanapun juga, penduduk lansia yang dibiarkan tanpa adanya jaminan kesehatan, akan berdampak buruk bagi status kesehatannya dan pada akhirnya akan rentan menjadi beban masyarakat (Adioetomo, Howell, Mc Pherson, \& Priebe, 2013).

Berbagai hal di atas menunjukkan bahwa kepemilikan jaminan kesehatan merupakan hal yang penting bagi penduduk lansia. Hal ini sebagai upaya mewujudkan penduduk lansia yang mandiri, sehat, aktif, dan produktif. Upaya ini tentu juga harus didukung dengan data-data atau kajian-kajian tentang penduduk lansia, khususnya terkait dengan jaminan kesehatan. Oleh karena itu, penelitian ini bertujuan untuk mengkaji pencapaian UHC di Indonesia dari sisi kepemilikan jaminan kesehatan penduduk lansia. Penelitian ini juga bertujuan untuk mengkaji faktor-faktor yang mempengaruhi kepemilikan jaminan kesehatan penduduk lansia di Indonesia.

\section{METODE}

Sumber data yang digunakan dalam penelitian ini adalah data sekunder hasil Susenas Maret 2018 yang diselenggarakan oleh BPS. Populasi Susenas Maret 2017 adalah seluruh rumah tangga di Indonesia. Adapun sampel Susenas Maret 2017 merupakan rumah tangga terpilih, yakni sebanyak 300.000 rumah tangga sampel. Berdasarkan sumber data tersebut, variabel yang diteliti adalah wilayah tempat tinggal, jenis kelamin, status perkawinan, umur, tingkat pendidikan, keluhan kesehatan, dan status ekonomi. Pada penelitian ini, variabel status ekonomi didekati dengan kelompok pengeluaran rumah tangga yakni 40 persen terbawah, 40 persen menengah, dan 20 persen teratas.

Metode analisis yang digunakan dalam penelitian ini adalah analisis deskriptif dan kuantitatif. Analisis deskriptif digunakan untuk mengkaji gambaran kepemilikan jaminan kesehatan penduduk lansia berdasarkan variabel-variabel yang diteliti. Hasil analisis ini kemudian disederhanakan ke 
dalam bentuk yang mudah dibaca dan diinterpretasikan yaitu melalui tabel distribusi frekuensi, diagram, dan teks. Sementara itu, analisis kuantitatif bertujuan untuk mengkaji faktor-faktor yang mempengaruhi kepemilikan jaminan kesehatan penduduk lansia. Uji statistik yang digunakan dalam analisis kuantitatif adalah uji chi square dengan $\mathrm{a}=0,05$ dan convidence interval sebesar 95 persen. Pada dasarnya uji chi square merupakan uji statistik nonparametrik yang digunakan untuk membandingkan apakah satu variabel tertentu bersifat dependen atau independen terhadap variabel yang lain (Sarwono \& Budiono, 2017).

\section{HASIL DAN PEMBAHASAN}

Tabel 1. Kepemilikan jaminan kesehatan berdasarkan karakteristik penduduk lansia Indonesia, 2017.

\begin{tabular}{|c|c|c|c|}
\hline \multirow{2}{*}{ Karakteristik } & \multirow{2}{*}{$\begin{array}{l}\text { Penduduk } \\
\text { Lansia } \\
(\%)\end{array}$} & \multicolumn{2}{|c|}{ Kepemilikan Jaminan Kesehatan (\%) } \\
\hline & & Ya & Tidak \\
\hline (1) & $(2)$ & (3) & (4) \\
\hline Total & 8,97 & 63,24 & 36,76 \\
\hline \multicolumn{4}{|l|}{ Wilayah Tempat Tinggal } \\
\hline Perkotaan & 49,64 & 67,53 & 32,47 \\
\hline Pedesaan & 50,36 & 59,01 & 40,99 \\
\hline \multicolumn{4}{|l|}{ Jenis Kelamin } \\
\hline Laki-laki & 47,48 & 63,63 & 36,37 \\
\hline Perempuan & 52,52 & 62,89 & 37,11 \\
\hline \multicolumn{4}{|l|}{ Status Perkawinan } \\
\hline Belum Kawin & 1,02 & 53,60 & 46,40 \\
\hline Kawin & 59,82 & 64,60 & 35,40 \\
\hline Cerai Hidup & 2,30 & 57,70 & 42,30 \\
\hline Cerai Mati & 36,85 & 61,60 & 38,40 \\
\hline \multicolumn{4}{|l|}{ Umur (tahun) } \\
\hline 60-69 (Lansia Muda) & 63,00 & 63,60 & 36,40 \\
\hline 70-79 (Lansia Madya) & 27,80 & 63,80 & 36,20 \\
\hline 80+ (Lansia Tua) & 9,20 & 59,00 & 41,00 \\
\hline \multicolumn{4}{|l|}{ Tingkat Pendidikan } \\
\hline Tidak pernah sekolah/Tidak tamat SD & 51,30 & 60,10 & 39,90 \\
\hline SD/Sederajat & 31,70 & 59,90 & 40,10 \\
\hline SMP/Sederajat & 6,40 & 69,20 & 30,80 \\
\hline SMA/Sederajat & 7,10 & 80,50 & 19,50 \\
\hline Diploma & 1,60 & 92,70 & 7,30 \\
\hline Sarjana & 1,90 & 94,70 & 5,30 \\
\hline \multicolumn{4}{|l|}{ Keluhan Kesehatan } \\
\hline Mengalami & 48,91 & 65,00 & 35,00 \\
\hline Tidak mengalami & 51,09 & 61,50 & 38,50 \\
\hline \multicolumn{4}{|l|}{ Status Ekonomi } \\
\hline 40 persen terbawah & 43,18 & 60,46 & 39,54 \\
\hline 40 persen menengah & 36,60 & 60,62 & 39,38 \\
\hline 20 persen teratas & 20,22 & 73,92 & 26,08 \\
\hline
\end{tabular}

Sumber: Susenas Maret 2017, diolah

Tabel 1 di atas menggambarkan penduduk lansia Indonesia didominasi oleh perempuan $(52,52$ persen), berstatus kawin (59,82 persen), dan tinggal di wilayah pedesaan (50,36 persen). Selain itu jika dilihat berdasarkan kelompok umur, penduduk lansia Indonesia sebagian besar berada pada 
kelompok umur lansia muda (60-69 tahun) yakni mencapai 63 persen. Adapun sisanya berada pada kelompok umur lansia madya (70-79 tahun) sebesar 27,8 persen dan lansia tua sebesar 9,2 persen (80 tahun ke atas).

Berdasarkan aspek pendidikan, sebagian besar penduduk lansia di Indonesia berpendidikan rendah. Persentase terbesar yaitu pada jenjang pendidikan SD ke bawah (tidak tamat SD dan tidak pernah sekolah). Bahkan hampir seperlima penduduk lansia di Indonesia tidak pernah sekolah. Angka tersebut masih lebih besar dibandingkan dengan persentase lansia yang memiliki ijazah SMP ke atas. Kondisi aspek pendidikan penduduk lansia ini secara tidak langsung merupakan gambaran kebijakan pembangunan pendidikan pada masa dahulu. Oleh karena itu, hal ini seharusnya menjadi pelajaran penting bagi pemerintah untuk memberikan bekal pendidikan yang baik dan berkualitas pada generasi saat ini. Pendidikan akan menjadi bekal yang berguna bagi mereka dalam menjalani masa tua dengan tetap mandiri, sehat, aktif, dan produktif.

Idealnya, ketika seseorang memasuki masa tua mereka telah memiliki kemapanan ekonomi, sehingga pada saat produktivitas mulai menurun kualitas hidup penduduk lansia tetap terjaga. Akan tetapi, potret yang terjadi saat ini masih terdapat penduduk lansia yang hidup dalam keterbatasan ekonomi. Dalam hal ini status ekonomi rumah tangga dilihat berdasarkan kelompok pengeluaran rumah tangga yang terdiri dari tiga kategori yaitu 40 persen terbawah (ekonomi rendah), 40 persen menengah (ekonomi menengah), dan 20 persen teratas (ekonomi tinggi).

Hasil penelitian, sebagaimana yang disajikan pada tabel 1, membuktikan bahwa penduduk lansia Indonesia masih didominasi oleh mereka yang tinggal di rumah tangga dengan kelompok pengeluaran 40 persen terbawah (43,18 persen) dan hanya sekitar 20,22 persen yang tinggal di rumah tangga dengan kelompok pengeluaran 20 persen teratas. Kondisi ini semakin menguatkan fenomena yang banyak terjadi pada negara berkembang, yakni penuaan penduduk tidak berbanding lurus dengan kemapanan ekonomi yang dimiliki. Hal ini sejalan dengan pernyataan yang diungkapkan oleh Adioetomo (2013) bahwa penduduk Indonesia getting older before getting rich atau menua sebelum kaya.

Sementara itu, berdasarkan aspek kesehatan, hasil penelitian menunjukkan hampir separuh penduduk lansia Indonesia mengalami keluhan kesehatan dalam sebulan terakhir. Keluhan kesehatan memang tidak selalu mengakibatkan terganggunya aktivitas sehari-hari, namun terjadinya keluhan kesehatan dan jenis keluhan yang dialami oleh penduduk dapat menggambarkan tingkat/derajat kesehatan secara kasar (Zaenurrohmah \& Rachmayanti, 2017). Keluhan kesehatan yang dialami penduduk lansia merupakan konsekuensi dari proses degeneratif yang terjadi seiring dengan pertambahan usia. Secara fisik, proses degeneratif adalah menghilangnya secara perlahanlahan kemampuan jaringan untuk memperbaiki diri, mengganti dan mempertahankan fungsi normalnya sehingga tidak dapat bertahan terhadap infeksi penyakit menular dan memperbaiki kerusakan yang diderita (Misnaniarti, 2017). Selain itu, keluhan kesehatan penduduk lansia juga merupakan konsekuensi dari proses penuaan yang menyebabkan penurunan fungsi fisiologis (Zaenurrohmah \& Rachmayanti, 2017). Hal ini lah yang mengakibatkan penyakit tidak menular relatif banyak terjadi pada penduduk lansia. Hasil-hasil kajian ini membuktikan bahwa penduduk lansia merupakan penduduk yang cenderung rentan terkena penyakit menular dan tidak menular.

Penduduk lansia seharusnya mengobati keluhan kesehatan yang dirasakannya, baik keluhan kesehatan yang mengganggu aktivitas sehar-hari maupun keluhan kesehatan yang tidak mengganggu aktivitas sehari-hari. Pengobatan ini dapat dilakukan secara mandiri atau dengan mendatangi tempat-tampat pelayanan kesehatan modern/tradisional. Pilihan langkah pengobatan ini tentu secara tidak langsung akan bergantung pada kepemilikan jaminan kesehatan penduduk lansia. Hasil penelitian sebagaimana tersaji pada tabel 1 justru menunjukkan bahwa jaminan kesehatan belum menjangkau seluruh penduduk lansia di Indonesia. Sistem JKN yang telah diberlakukan sejak tahun 2014, hanya dapat menjangkau sekitar 63,24 persen penduduk lansia di Indonesia. Dengan demikian, dalam aspek penduduk lansia, Indonesia masih relatif jauh dari target UHC yakni minimal 95 persen dari populasi. Oleh karena itu, pemerintah harus terus berupaya memperluas cakupan jaminan kesehatan penduduk lansia melalui sosialisasi dan promosi di berbagai media. Sosialisasi ataupun promosi ini khususnya ditujukan kepada penduduk lansia yang berumur 80 tahun ke atas, tinggal di pedesaan, dan termasuk ke dalam kelompok pengeluaran 40 persen 
terbawah. Hal ini sangat penting dilakukan agar program sosialisasi dan promosi dapat berjalan efektif dan efisien.

Tabel 2. Jenis jaminan kesehatan berdasarkan karakteristik penduduk lansia Indonesia, 2017.

Jenis Jaminan Kesehatan (\%)

\begin{tabular}{|c|c|c|c|c|c|}
\hline Karakteristik & $\begin{array}{c}\text { Penerima } \\
\text { Bantuan } \\
\text { Iuran } \\
\text { (PBI) }\end{array}$ & $\begin{array}{l}\text { Non } \\
\text { PBI }\end{array}$ & Jamkesda & $\begin{array}{l}\text { Asuransi } \\
\text { Swasta }\end{array}$ & Perusahaan \\
\hline (1) & (2) & (3) & (4) & (5) & (6) \\
\hline Total & 33,47 & 17,08 & 12,88 & 0,83 & 1,51 \\
\hline \multicolumn{6}{|l|}{ Wilayah Tempat Tinggal } \\
\hline Perkotaan & 31,25 & 24,61 & 10,54 & 1,41 & 2,69 \\
\hline Pedesaan & 35,67 & 9,65 & 15,18 & 0,25 & 0,35 \\
\hline \multicolumn{6}{|l|}{ Jenis Kelamin } \\
\hline Laki-laki & 33,18 & 17,72 & 12,60 & 0,88 & 1,77 \\
\hline Perempuan & 33,73 & 16,49 & 13,13 & 0,78 & 1,28 \\
\hline \multicolumn{6}{|l|}{ Status Perkawinan } \\
\hline Belum Kawin & 28,90 & 13,80 & 11,90 & 0,90 & 0,50 \\
\hline Kawin & 33,30 & 18,50 & 12,60 & 1,00 & 1,80 \\
\hline Cerai Hidup & 33,30 & 11,10 & 13,50 & 0,90 & 1,30 \\
\hline Cerai Mati & 33,80 & 15,30 & 13,30 & 0,60 & 1,10 \\
\hline \multicolumn{6}{|l|}{ Umur (tahun) } \\
\hline 60-69 (Lansia Muda) & 32,70 & 17,90 & 12,80 & 1,00 & 1,70 \\
\hline 70-79 (Lansia Madya) & 35,10 & 16,50 & 12,90 & 0,60 & 1,30 \\
\hline $80+($ Lansia Tua $)$ & 33,60 & 12,90 & 13,40 & 0,60 & 0,70 \\
\hline \multicolumn{6}{|l|}{ Tingkat Pendidikan } \\
\hline Tidak pernah sekolah/Tidak tamat SD & 36,90 & 10,40 & 14,10 & 0,40 & 0,70 \\
\hline SD/Sederajat & 32,80 & 14,60 & 13,30 & 0,40 & 0,90 \\
\hline SMP/Sederajat & 26,60 & 30,10 & 10,60 & 1,80 & 3,20 \\
\hline SMA/Sederajat & 23,90 & 44,40 & 7,60 & 3,20 & 5,60 \\
\hline Diploma & 22,30 & 57,30 & 5,60 & 2,40 & 9,20 \\
\hline Sarjana & 22,00 & 58,50 & 5,70 & 6,30 & 8,00 \\
\hline \multicolumn{6}{|l|}{ Keluhan Kesehatan } \\
\hline Mengalami & 35,60 & 17,00 & 13,10 & 0,70 & 1,40 \\
\hline Tidak mengalami & 31,50 & 17,10 & 12,60 & 0,90 & 1,70 \\
\hline \multicolumn{6}{|l|}{ Status Ekonomi } \\
\hline 40 persen terbawah & 40,34 & 7,92 & 13,73 & 0,20 & 0,37 \\
\hline 40 persen menengah & 31,51 & 16,29 & 13,48 & 0,42 & 1,16 \\
\hline 20 persen teratas & 22,34 & 38,04 & 9,97 & 2,91 & 4,58 \\
\hline
\end{tabular}

Sumber: Susenas Maret 2017, diolah

Berdasarkan jenis jaminan kesehatan, tabel 2 di atas menunjukkan bahwa jaminan kesehatan yang paling banyak dimiliki oleh penduduk lansia adalah BPJS Kesehatan Penerima Bantuan Iuran (PBI), yaitu sebesar 33,47 persen. Sedangkan jaminan kesehatan yang paling sedikit dimiliki penduduk lansia adalah asuransi perusahaan, yakni sebesar 0,83 persen. Kondisi ini mengindikasikan bahwa penduduk lansia di Indonesia masih tergantung pada bantuan pembiayaan jaminan kesehatan dari pemerintah.

Pada dasarnya program bantuan pembiayaan jaminan kesehatan merupakan upaya pemerintah untuk meningkatkan akses terhadap pelayanan kesehatan bagi masyarakat miskin dan rentan serta 
memberikan perlindungan keuangan atas pengeluaran kesehatan akibat sakit. Sayangnya, program tersebut belum sepenuhnya tepat sasaran. Tabel 2 di atas menunjukkan masih terdapat 22,34 persen penduduk lansia dengan status ekonomi 20 persen teratas yang justru merupakan PBI. Sementara itu, tercatat baru sekitar 40,34 persen penduduk lansia dengan status ekonomi 40\% terbawah yang merupakan PBI. Padahal, mereka lah yang seharusnya lebih berhak memperoleh bantuan pembiayaan jaminan kesehatan dari pemerintah. Oleh karena itu, pemerintah harus melakukan evaluasi terhadap mekanisme penyaluran bantuan pembiayaan jaminan kesehatan. Dalam konteks ini, maka data yang berkualitas sangat diperlukan sebagai dasar pengambilan kebijakan dalam menentukan rumah tangga sasaran program pembiayaan jaminan kesehatan.

Tabel 3. Determinan kepemilikan jaminan kesehatan penduduk lansia Indonesia, 2017.

\begin{tabular}{|c|c|c|c|c|c|c|}
\hline \multirow{2}{*}{ Karakteristik } & \multicolumn{2}{|c|}{$\begin{array}{c}\text { Kepemilikan } \\
\text { Jaminan Kesehatan } \\
(\%)\end{array}$} & \multirow{2}{*}{$\begin{array}{c}\mathbf{P} \\
\text { Value }\end{array}$} & \multirow{2}{*}{$\begin{array}{l}\text { Odd } \\
\text { Ratio } \\
\text { (OR) }\end{array}$} & \multicolumn{2}{|c|}{$\begin{array}{c}\text { Confidence } \\
\text { Interval 95\% }\end{array}$} \\
\hline & $\mathbf{Y a}$ & Tidak & & & Lower & Upper \\
\hline (1) & (2) & (3) & (4) & (5) & (6) & (7) \\
\hline \multicolumn{7}{|l|}{ Wilayah Tempat Tinggal } \\
\hline Perkotaan & 67,53 & 32,47 & & & & \\
\hline Pedesaan & 59,01 & 40,99 & 0,000 & 1,445 & 1,442 & 1,447 \\
\hline \multicolumn{7}{|l|}{ Jenis Kelamin } \\
\hline Laki-laki & 63,63 & 36,37 & & & & \\
\hline Perempuan & 62,89 & 37,11 & 0,000 & 1,032 & 1,031 & 1,034 \\
\hline \multicolumn{7}{|l|}{ Status Perkawinan } \\
\hline Belum Kawin & 53,60 & 46,40 & & & & \\
\hline Kawin & 64,60 & 35,40 & 0,000 & 0,633 & 0,628 & 0,638 \\
\hline Cerai Hidup & 57,70 & 42,30 & 0,000 & 0,848 & 0,840 & 0,857 \\
\hline Cerai Mati & 61,60 & 38,40 & 0,000 & 0,720 & 0,714 & 0,726 \\
\hline \multicolumn{7}{|l|}{ Umur (tahun) } \\
\hline 60-69 (Lansia Muda) & 63,60 & 36,40 & & & & \\
\hline 70-79 (Lansia Madya) & 63,80 & 36,20 & 0,000 & 0,994 & 0,992 & 0,996 \\
\hline $80+($ Lansia Tua $)$ & 59,00 & 41,00 & 0,000 & 1,214 & 1,210 & 1,217 \\
\hline \multicolumn{7}{|l|}{ Tingkat Pendidikan } \\
\hline Tidak pernah sekolah/Tidak tamat SD & 60,10 & 39,90 & & & & \\
\hline SD/Sederajat & 59,90 & 40,10 & 0,000 & 1,006 & 1,004 & 1,008 \\
\hline SMP/Sederajat & 69,20 & 30,80 & 0,000 & 0,668 & 0,666 & 0,671 \\
\hline SMA/Sederajat & 80,50 & 19,50 & 0,000 & 0,366 & 0,364 & 0,367 \\
\hline Diploma & 92,70 & 7,30 & 0,000 & 0,119 & 0,118 & 0,121 \\
\hline Sarjana & 94,70 & 5,30 & 0,000 & 0,084 & 0,083 & 0,086 \\
\hline \multicolumn{7}{|l|}{ Keluhan Kesehatan } \\
\hline Tidak mengalami & 61,50 & 38,50 & & & & \\
\hline Mengalami & 65,00 & 35,00 & 0,000 & 1,165 & 1,163 & 1,167 \\
\hline \multicolumn{7}{|l|}{ Status Ekonomi } \\
\hline 40 persen terbawah & 60,46 & 39,54 & & & & \\
\hline 40 persen menengah & 60,62 & 39,38 & 0,000 & 0,930 & 0,928 & 0,931 \\
\hline 20 persen teratas & 73,92 & 26,08 & 0,000 & 0,649 & 0,647 & 0,650 \\
\hline
\end{tabular}

Sumber: Susenas Maret 2017, diolah.

Tabel 3 di atas menunjukkan bahwa berdasarkan wilayah tempat tinggal, proporsi penduduk lansia perkotaan yang memiliki jaminan kesehatan lebih besar dibandingkan dengan pedesaan, yakni 67,53 persen berbanding 59,01 persen. Secara statistik, uji chi square menghasilkan $P$ Value sebesar 
0,000 lebih kecil dari 0,05. Hal ini menunjukkan terdapat hubungan signifikan antara wilayah tempat tinggal dengan kepemilikan jaminan kesehatan penduduk lansia. Sementara itu, dengan confidence interval 95 persen, diperoleh nilai odd ratio sebesar 1,445. Hal ini berarti penduduk lansia yang tinggal di pedesaan berpeluang memiliki jaminan kesehatan 1,445 kali dibandingkan dengan penduduk lansia perkotaan.

Berdasarkan jenis kelamin, proporsi penduduk lansia laki-laki yang memiliki jaminan kesehatan lebih besar dibandingkan dengan perempuan, yakni 63,63 persen berbanding 62,89 persen. Secara statistik, uji chi square menghasilkan $P$ Value sebesar 0,000 lebih kecil dari 0,05. Hal ini menunjukkan terdapat hubungan signifikan antara jenis kelamin dengan kepemilikan jaminan kesehatan penduduk lansia. Sementara itu, dengan confidence interva/95 persen, diperoleh nilai odd ratio sebesar 1,032. Hal ini berarti penduduk lansia perempuan berpeluang memiliki jaminan kesehatan 1,032 kali dibandingkan dengan penduduk lansia laki-laki.

Berdasarkan status perkawinan, penduduk lansia berstatus kawin mempunyai proporsi terbesar (64,60 persen) dalam memiliki jaminan kesehatan dibandingkan dengan penduduk lansia berstatus belum kawin, cerai hidup, dan cerai mati. Secara statistik, uji chi square menghasilkan $P$ Value sebesar 0,000 lebih kecil dari 0,05. Hal ini menunjukkan terdapat hubungan signifikan antara status perkawinan dengan kepemilikan jaminan kesehatan penduduk lansia. Sementara itu, untuk status kawin dengan confidence interval 95 persen, diperoleh nilai odd ratio sebesar 0,633. Hal ini berarti penduduk lansia berstatus kawin berpeluang memiliki jaminan kesehatan 0,633 kali dibandingkan dengan penduduk lansia berstatus belum kawin. Sedangkan untuk status cerai hidup, diperoleh nilai odd ratio sebesar 0,848 yang berarti penduduk lansia berstatus cerai hidup berpeluang memiliki jaminan kesehatan 0,848 kali dibandingkan dengan penduduk lansia berstatus belum kawin. Adapun untuk status cerai mati, diperoleh nilai odd ratio sebesar 0,720 yang berarti penduduk lansia berstatus cerai mati berpeluang memiliki jaminan kesehatan 0,720 kali dibandingkan dengan penduduk lansia berstatus belum kawin.

Berdasarkan kelompok umur, penduduk lansia madya (70-79 tahun) mempunyai proporsi terbesar (63,80 persen) dalam memiliki jaminan kesehatan dibandingkan dengan penduduk lansia muda (60-69 tahun) dan lansia tua (80 tahun ke atas). Secara statistik, uji chi square menghasilkan $P$ Value sebesar 0,000 lebih kecil dari 0,05. Hal ini menunjukkan terdapat hubungan signifikan antara umur dengan kepemilikan jaminan kesehatan penduduk lansia. Sementara itu, untuk penduduk lansia madya dengan confidence interval 95 persen, diperoleh nilai odd ratio sebesar 0,994. Hal ini berarti penduduk lansia madya berpeluang memiliki jaminan kesehatan 0,994 kali dibandingkan dengan penduduk lansia muda. Sedangkan untuk penduduk lansia tua, diperoleh nilai odd ratio sebesar 1,214 yang berarti penduduk lansia tua berpeluang memiliki jaminan kesehatan 1,214 kali dibandingkan dengan penduduk lansia muda.

Berdasarkan tingkat pendidikan, penduduk lansia dengan tingkat pendidikan sarjana mempunyai proporsi terbesar ( 94,70 persen) dalam memiliki jaminan kesehatan dibandingkan dengan penduduk lansia dengan tingkat pendidikan tidak pernah bersekolah/tidak tamat SD, tamat SD, SMP, SMA, dan diploma. Secara statistik, uji chi square menghasilkan $P$ Value sebesar 0,000 lebih kecil dari 0,05 . Hal ini menunjukkan terdapat hubungan signifikan antara tingkat pendidikan dengan kepemilikan jaminan kesehatan penduduk lansia. Sementara itu, untuk tingkat pendidikan SD dengan confidence interval 95 persen, diperoleh nilai odd ratio sebesar 1,006 . Hal ini berarti penduduk lansia berpendidikan SD berpeluang memiliki jaminan kesehatan 1,006 kali dibandingkan dengan penduduk lansia yang tidak pernah bersekolah/tidak tamat SD. Sedangkan untuk penduduk lansia berpendidikan SMP, diperoleh nilai odd ratio sebesar 0,668 yang berarti penduduk lansia berpendidikan SMP berpeluang memiliki jaminan kesehatan 0,668 kali dibandingkan dengan penduduk lansia yang tidak pernah bersekolah/tidak tamat SD. Adapun untuk penduduk lansia berpendidikan SMA, diperoleh nilai odd ratio sebesar 0,366 yang berarti penduduk lansia berpendidikan SMA berpeluang memiliki jaminan kesehatan 0,366 kali dibandingkan dengan penduduk lansia yang tidak pernah bersekolah/tidak tamat SD. Sementara itu untuk penduduk lansia berpendidikan diploma dan sarjana, diperoleh nilai odd ratio masing-masing sebesar 0,119 dan 0,084 . Hal ini berarti penduduk lansia berpendidikan diploma dan sarjana masing-masing berpeluang 
memiliki jaminan kesehatan 0,119 dan 0,084 kali dibandingkan dengan penduduk lansia yang tidak pernah bersekolah/tidak tamat SD.

Keterkaitan antara tingkat pendidikan dengan kepemilikan jaminan kesehatan telah dibuktikan dalam beberapa penelitian terdahulu. Gerungan (2004) berpendapat bahwa semakin tinggi pendidikan akan mempengaruhi pribadi seseorang dalam berfikir, bersikap, mengambil keputusan, termasuk dalam merencanakan kesehatan salah satunya yaitu dengan mengikuti JKN. Pendapat ini diperkuat dengan hasil kajian yang menunjukkan ada hubungan antara pendidikan dengan pemilihan jenis iuran JKN mandiri/non PBI (Rohmawati, 2014). Hasil senada juga ditunjukkan oleh kajian yang dilakukan Amu \& Dickson (2016) di Ghana yang menunjukkan bahwa masyarakat berpendidikan tinggi memiliki pandangan yang lebih tinggi berkaitan dengan perlunya memiliki asuransi kesehatan untuk menghadapi masalah kesehatan yang tidak terduga, sedangkan masyarakat berpendidikan rendah tidak menyadari tingkat ancaman yang akan ditimbulkan terkait masalah kesehatan yang tak terduga. Hasil penelitian ini sejalan dengan hasil kajian oleh Intiasari, Trisnantoro, dan Hendrartini (2015) terhadap para pekerja informal di Indonesia yang menunjukkan bahwa terdapat hubungan antara pendidikan dengan keikutsertaan jaminan kesehatan. Mereka yang tamat SMA memiliki kemungkinan 10,3 kali lebih tinggi dan lulusan D1/D2/D3 memiliki kemungkinan 38,1 kali lebih tinggi untuk mempunyai asuransi kesehatan sukarela dibandingkan dengan mereka yang tidak sekolah.

Berdasarkan keluhan kesehatan, penduduk lansia yang mengalami keluhan kesehatan mempunyai proporsi lebih besar (65 persen) dalam memiliki jaminan kesehatan dibandingkan dengan penduduk lansia yang tidak mengalami keluhan kesehatan. Secara statistik, uji chi square menghasilkan $P$ Value sebesar 0,000 lebih kecil dari 0,05. Hal ini menunjukkan terdapat hubungan signifikan antara keluhan kesehatan dengan kepemilikan jaminan kesehatan penduduk lansia. Sementara itu, dengan confidence interval 95 persen, diperoleh nilai odd ratio sebesar 1,165. Hal ini berarti penduduk lansia yang mengalami keluhan kesehatan berpeluang memiliki jaminan kesehatan 1,165 kali dibandingkan dengan penduduk lansia yang tidak mengalami keluhan kesehatan.

Berdasarkan status ekonomi, penduduk lansia dengan status ekonomi tinggi mempunyai proporsi terbesar (73,92 persen) dalam memiliki jaminan kesehatan dibandingkan dengan penduduk lansia dengan status ekonomi rendah dan menengah. Secara statistik, uji chi square menghasilkan $P$ Value sebesar 0,000 lebih kecil dari 0,05. Hal ini menunjukkan terdapat hubungan signifikan antara status ekonomi dengan kepemilikan jaminan kesehatan penduduk lansia. Sementara itu, untuk penduduk lansia berstatus ekonomi menengah dengan confidence interva/95 persen, diperoleh nilai odd ratio sebesar 0,930. Hal ini berarti penduduk lansia berstatus ekonomi menengah berpeluang memiliki jaminan kesehatan 0,930 kali dibandingkan dengan penduduk lansia berstatus ekonomi rendah. Sedangkan untuk penduduk lansia berstatus ekonomi tinggi, diperoleh nilai odd ratio sebesar 0,649 yang berarti penduduk lansia berstatus ekonomi tinggi berpeluang memiliki jaminan kesehatan 0,649 kali dibandingkan dengan penduduk lansia berstatus ekonomi rendah.

\section{KESIMPULAN}

Indonesia saat ini telah memasuki era Ageing Population, dengan persentase penduduk lansia sebesar 8,97 persen. Berdasarkan karaktersitik sosiodemografi, penduduk lansia Indonesia didominasi oleh perempuan, berumur 60-69 tahun, berstatus kawin, berpendidikan SD ke bawah, tinggal di wilayah pedesaan dan berada pada rumah tangga dengan kelompok pengeluaran 40 persen terbawah. Dalam konteks pembangunan kesehatan, pemerintah menghadapi tiga tantangan. Pertama, UHC di Indonesia belum mampu menjangkau seluruh penduduk lansia Indonesia. Kedua, penduduk lansia Indonesia masih tergantung pada bantuan pembiayaan jaminan kesehatan dari pemerintah. Ketiga, program bantuan pembiayaan jaminan kesehatan belum tepat sasaran, sebab masih terdapat penduduk lansia dengan status ekonomi tinggi yang menerima program bantuan tersebut. Sementara itu, determinan kepemilikan jaminan kesehatan penduduk lansia Indonesia adalah wilayah tempat tinggal, jenis kelamin, status perkawinan, tingkat pendidikan, keluhan kesehatan dan status ekonomi. Dengan demikian,sebagai upaya dalam menjalankan amanah SDG's, 
pemerintah harus terus memperluas jangkauan UHC melalui program-program perlindungan kesehatan bagi penduduk lansia. Program-program ini hendaknya juga harus didasarkan pada karakteristik penduduk lansia di setiap wilayah Indonesia.

\section{DAFTAR PUSTAKA}

Adioetomo, S. M. (2013). Ageing Monograph: Evidence from the 2010 Census. Jakarta: UNFPA Indonesia.

Adioetomo, S. M., Howell, F., Mc Pherson, A., \& Priebe, J. (2013). Asistensi Sosial Untuk Usia Lanjut di Indonesia: Kajian Empiris Program Asistensi Sosial Lanjut Usia Terlantar. Jakarta: TNP2K.

Agustina, R., Dartanto, T., Sitompul, R., Susiloretni, K. A., Achadi, E. L., Taher, A., ... Sungkar, S. (2019). Review Universal Health Coverage in Indonesia: Concept, Progress, and Challenges. The Lancet, 393, 75-102.

Ahoobim, O., Garrett, L., Hausman, V., \& Huang, Y. (2012). The New Global Health Agenda: Universal Health Coverage. New York.

Amu, \& Dickson. (2016). Health Insurance Subscription among Women in Reproductive Age in Ghana: Do Socio-demographics Matter? Health Economics Review, 6(24), 1-8.

Boerma, T., Eozenou, P., Evans, D., Evans, T., Kieny, M. P., \& Wagstaff, A. (2014). Monitoring Progress towards Universal Health Coverage at Country and Global Levels. PLoS Medicine, 11(9), 1-8. https://doi.org/10.1371/journal.pmed.1001731

BPJS Kesehatan. (2016). Ringkasan Eksekutif Laporan Pengelolaan Program dan Laporan Keuangan Jaminan Sosial Kesehatan Tahun 2016. Jakarta: BPJS Kesehatan.

BPJS Kesehatan. (2019). Peserta Program JKN per 31 Agustus 2019. Retrieved September 2, 2019, from https://bpjs-kesehatan.go.id/bpjs/home

BPS. (2018a). Indikator Pembangunan Berkelanjutan (TPB) Indonesia 2018. Jakarta: Badan Pusat Statistik.

BPS. (2018b). Statistik Penduduk Lanjut Usia 2018. Jakarta: Badan Pusat Statistik. https://doi.org/10.1192/bjp.112.483.211-a

Dartanto, T., Hanum, C., Usman, Bintara, H., Bella, A., \& Putro, P. (2017). Dampak Program JKN-KIS pada Perekonomian Indonesia. Ringkasan Riset JKN-KIS, 01(Agustus), 1-8. Retrieved from https://bpjskesehatan.go.id/bpjs/dmdocuments/22307a61e9670fee4d14b5138241507e.pdf

Gerungan. (2004). Psikologi Sosial. Bandung: PT. Refika Aditama.

Intiasari, Trisnantoro, \& Hendrartini. (2015). Potret Masyarakat Sektor Informal di Indonesia: Mengenal Determinan Probabilitas Keikutsertaan Jaminan Kesehatan Sebagai Upaya Perluasan Kepesertaan Pada Skema Non PBI Mandiri. Jurnal Kebijakan Kesehatan Indonesia, 4(4), 126-132.

Marten, R., McIntyre, D., Travassos, C., Shishkin, S., Longde, W., Reddy, S., \& Vega, J. (2014). An Assessment of Progress towards Universal Health Coverage in Brazil, Russia, India, China, and South Africa (BRICS). The Lancet, 384(9960), 2164-2171. https://doi.org/10.1016/S0140-6736(14)60075-1

Misnaniarti. (2017). Analisis Situasi Penduduk Lanjut Usia dan Upaya Peningkatan Kesejahteraan Sosial di Indonesia. Kesehatan Masyarakat, 8(2), 67-73.

Rohmawati, D. (2014). Hubungan pengetahuan sikap dan sosial ekonomi dengan pemilihan jenis iuran keikutsertaan JKN mandiri pada wilayah cakupan JKN tertinggi di Surakarta. Surakarta.

Sarwono, J., \& Budiono, H. (2017). Statistik Terapan: Aplikasi untuk Riset Skripsi, Tesis, dan Disertasi (Menggunakan SPSS, AMOS, dan Excel). Jakarta: PT. Elex Media Computindo.

United Nations. (2017). World Population Prospects the 2017 Revision, Key Findings and Advance tables. New York.

WHO. (2015). Tracking Universal Health Coverage. First Global Monitoring Report. Geneva. Retrieved from http//:www.who.int/about/licensing/copyright_form/en/index.html

Zaenurrohmah, D. H., \& Rachmayanti, R. D. (2017). Hubungan Pengetahuan dan Riwayat Hipertensi dengan Tindakan Pengendalian Tekanan Darah pada Lansia. Jurnal Berkala Epidemiologi, 5(2), 174-184. https://doi.org/10.20473/jbe.v5i2.2017.174-184 